This journal provides immediate open access to its content under the Creative Commons BY 4.0 license. Authors who publish with this journal retain all copyrights and agree to the terms of the above-mentioned CC BY 4.0 license.

DOI: $10.2478 /$ seeur-2020-0006

\title{
ONLINE LEARNING BENEFITS AND CHALLENGES DURING THE COVID 19 - PANDEMIC- STUDENTS' PERSPECTIVE FROM SEEU
}

Prof. Dr. Brikena Xhaferi,

Faculty of Languages, Cultures and Communication, South East European University, North Macedonia

b.xhaferi@seeu.edu.mk

Prof. Dr. Gëzim Xhaferi,

Faculty of Languages, Cultures and Communication, South East European University, North Macedonia

g.xhaferi@seeu.edu.mk

\begin{abstract}
Online learning is becoming a commonplace in different settings starting from elementary, secondary and higher levels of education. Different educational institutions use different communication tools to promote learning because the expansive nature of the Internet and the accessibility of technology have generated a surge in the demand for web-based teaching and learning across the nations (Chaney, 2010). The online teaching and learning have become a necessity for education around the globe during COVID 19-pandemic. There are several challenges which are faced during online classes because the students must have strong self-motivation skills and be very disciplined to achieve the desired learning results.

This paper presents and analyzes the data on the benefits and challenges of online teaching at South East European University (SEEU) during COVID 19 pandemic. The participants of the study are students of the BA level majoring in English Language and Literature and German Language and Literature at SEEU in Tetovo, North Macedonia. To
\end{abstract}


answer the research questions, we have used a student questionnaire, interviews, and student reflection papers written during the online courses.

Overall, the research indicates that benefits of online coursework outweigh the challenges that students face during the online classes. From a safety perspective, this study emphasizes the need to consider the impact of online teaching on student motivation and the paper raises important questions about how to best support students enrolled in online courses. Further research is needed in order to better evaluate the benefits, challenges, and useful strategies of successful students enrolled in online courses.

Keywords: COVID-19 pandemic, Online teaching and learning, University Level, students of English and German languages.

\section{INTRODUCTION}

The widespread use of technology nowadays offers learners and teachers different tools which can facilitate language learning and teaching across universities in different parts of the world. With the ability of the Internet to cut across demographic boundaries online, education has rapidly become not just an acceptable pedagogy, but one that is in strong demand (Cahoon, 1998). The research context, South East European University (SEEU) in Tetovo, North Macedonia, is an institution which has used a hybrid approach to learning/teaching through different online platforms such as ANGEL, LIBRI, and most recently Google Classroom. However, due to COVID- 19 pandemic, this mode of teaching was shifted to online teaching using Google Classroom and Google Meet. For teachers and students this was a challenging semester even though SEEU staff members regularly attend professional development training sessions and have an efficient IT support office, computer labs and classrooms which are very well equipped with technology.

It is often argued that the progress and delivery of good online courses depends on how traditional pedagogy is transferred to online environment (Sloboda, 2005). Research done recently revealed that "students in online classes (1) have greater control over their learning (Sloboda, 2005 as cited in Stone and Perumean-Chaney, 2005, p.394), (2) experience high levels of interactivity with other students, and (3) are able to construct new knowledge (Eastmond, 1998 Stone and Perumean-Chaney, 2005, p.394 )”. Even though the students mentioned many benefits of online learning "there are considerable structural, psychological, and pedagogical challenges in shifting instruction that occurs spontaneously in the traditional 
classroom to cyber-rooms on the Internet" (Stone and Perumean-Chaney, 2005, p.394). Evans and Fan (2002 cited in O'Donoghue, Singh and Green, 2004, p. 65), on the other hand, pointed out three main advantages to online learning: "1) learner-determined location for learning whereby students are able to choose their own place of study; 2) learner-determined time of learning - students are able to organize their own individual learning schedule, $\ldots$... and finally; 3) learner-determined pace of study - students are able to set their own individual pace of study...".

Despite the fact that some institutions have not used the online platforms previously, due to the lack of information technology (IT) infrastructure, they were forced to start using Google Meet or Zoom video conferencing service which allow up to 100 participants in virtual meetings for free. Both teachers and students meet regularly in online classes using these two services and discuss the topics strictly following the course syllabus. Google Classroom is used for sharing course materials, online discussions, announcements and evaluating students' assignments.

With the appearance of the first human cases of COVID-19, in Wuhan City, China, in December 2019, the virus was quickly spreading over the world with many victims and other consequences, observed in all segments of life impacting mostly global economy and education. In the Executive summary posted by the United Nations (August, 2020) it is stated, "The COVID-19 pandemic has created the largest disruption of education systems in history, affecting nearly 1.6 billion learners in more than 190 countries and all continents. Closures of schools and other learning spaces have impacted 94 per cent of the world's student population, up to 99 per cent in low and lower-middle income countries" (p.2).

The shift from a hybrid approach to teaching and learning worldwide into a full online teaching mode, can have many challenges. In different environments, students do not have "reliable internet access and/or technology and they struggle to participate in digital learning; this gap is seen across countries and between income brackets within countries... whilst $95 \%$ of students in Switzerland, Norway, and Austria have a computer to use for their schoolwork, only 34\% in Indonesia do". (The World Economic Forum COVID Action Platform, 2020, NP). It is further stated that in the USA, for example, nearly $25 \%$ of the students from poor families reported that they do not have a computer at home while the government of Australia has provided computers to all students in need fearing that the pandemic widens the digital divide. 
Going through the literature review, it can be concluded that educational institutions worldwide are struggling to offer the best possible learning opportunities for their students in order to avoid a complete closure of schools and universities by including them in online classes.

\section{RESEARCH QUESTIONS}

The study aimed to answer the following research questions:

Q1: What are the students' perceptions of online teaching at SEEU during the COVID 19pandemic?

Q2: What are the main challenges that the students faced during their online classes?

Q3: Which were the most posted online activities by the teachers?

\section{RESEARCH PARTICIPANTS}

There were 65 students of English and German Departments of the Faculty of Languages Cultures and Communication involved in the research. The students' age ranged from 19-22 and they were of both genders, male and female. They belonged to different ethnic groups, Albanian, Macedonian, Turkish and Roma. The students were attending the $2^{\text {nd }}$ and $3^{\text {rd }}$ year of their BA studies

\section{RESEARCH RESULTS}

The first instrument used was the student questionnaire which contained 15 questions. It was composed by the researchers based on the literature review. The students circled the answer that best applied to them. 


\begin{tabular}{|l|l|l|l|l|l|}
\hline Items & never & rarely & sometimes & often & always \\
\hline $\begin{array}{l}\text { 1. What was the frequency of your enrollment } \\
\text { in online courses last semester? }\end{array}$ & & & & & $100 \%$ \\
\hline $\begin{array}{l}\text { 2. Do you think that online learning is a } \\
\text { good solution for a pandemic period? }\end{array}$ & $/$ & $10 \%$ & $35 \%$ & $25 \%$ & $30 \%$ \\
\hline 3. Have you faced any difficulties during online classes & $10 \%$ & $20 \%$ & $55 \%$ & $15 \%$ & $/$ \\
\hline $\begin{array}{l}\text { 4. Do you think that you have been a } \\
\text { successful online learner? }\end{array}$ & $15 \%$ & $50 \%$ & $15 \%$ & $20 \%$ & $/$ \\
\hline $\begin{array}{l}\text { 5. Do you think that teachers were good at } \\
\text { online teaching? }\end{array}$ & $5 \%$ & $15 \%$ & $70 \%$ & $10 \%$ & \\
\hline $\begin{array}{l}\text { 6. Were you given too much homework } \\
\text { during the online classes? }\end{array}$ & $/$ & $/$ & $10 \%$ & $30 \%$ & $60 \%$ \\
\hline $\begin{array}{l}\text { 7.Were there confusing aspects to the } \\
\text { setup of the course? }\end{array}$ & $/$ & $10 \%$ & $45 \%$ & $30 \%$ & $15 \%$ \\
\hline $\begin{array}{l}\text { 8. Do you believe that whiteboard is } \\
\text { a useful tool for teaching/learning? }\end{array}$ & $/$ & $/$ & $5 \%$ & $10 \%$ & $85 \%$ \\
\hline $\begin{array}{l}\text { 9. Do you think that the online learning } \\
\text { community differs from a traditional setting? }\end{array}$ & $10 \%$ & $/$ & $35 \%$ & $40 \%$ & $15 \%$ \\
\hline $\begin{array}{l}\text { 10. Did the online setting affect the discussion } \\
\text { between you and your peers? }\end{array}$ & $15 \%$ & $20 \%$ & $30 \%$ & $15 \%$ & $20 \%$ \\
\hline $\begin{array}{l}\text { 11. Did the online setting affect the discussion } \\
\text { between you and your teacher? }\end{array}$ & $10 \%$ & $20 \%$ & $15 \%$ & $45 \%$ & $10 \%$ \\
\hline $\begin{array}{l}\text { 12. Are there pieces of the traditional classroom setting } \\
\text { that are lost in an online course? }\end{array}$ & $/$ & $/$ & $10 \%$ & $30 \%$ & $60 \%$ \\
\hline $\begin{array}{l}\text { 13. Do you need face-to-face interaction with } \\
\text { your peers and instructors to succeed? }\end{array}$ & $20 \%$ & $10 \%$ & $15 \%$ & $25 \%$ & $30 \%$ \\
\hline $\begin{array}{l}\text { 14. Were the assessment and evaluation fair } \\
\text { and objective? }\end{array}$ & $10 \%$ & $25 \%$ & $25 \%$ & $40 \%$ \\
\hline 15.Would you take an online course in the future? & & & & \\
\hline
\end{tabular}

Table 1: Students' questionnaire results

From the results presented in Table 1, the most significant items are the ones related to student participation in online courses (100\%), online learning community is different from the traditional setting (85\%), too much homework was given to the students $(60 \%)$, and pieces of the traditional classroom setting are lost in an online course (60\%). It seems that the participants are aware of the differences between traditional and online setting which can increase students' interest in learning. One area of improvement and one of the main critics is directed towards the teachers who give the students too much homework. It is very important, that teachers need to take special care when assigning homework because it should be a short assignment as an extension of what students have learned in class.

According to the questionnaire results, $40 \%$ of the participants believed that testing and evaluation were fair and objective which is very important for student motivation in learning. While, one third of the participants (30\%) always consider online learning as a good solution 
for a pandemic situation; similarly, $30 \%$ believed that face-to-face interaction with their peers and instructors is needed for them to succeed. Generally, even though the students find online learning as a good solution for pandemic period they equally think that interaction with peers and teachers in in-class setting way increase their language achievement.

Also, the results of two similar statements related to the level of discussion in an online setting between the peers themselves and with the teacher, reveal that it is not affected very much. Namely, only $15 \%$ of the participants believed that the discussion between the peers is always affected in such a learning environment and $20 \%$ of them stated that the discussion with the teacher is always affected by online learning. It seems that students discuss learning issues in online classes because it is mutually beneficial and involves the sharing of knowledge, ideas and experience between the participants.

Regarding the technical sides of online teaching, we can see that only $15 \%$ of the participants stated that the whiteboard is always a useful tool for teaching/learning. While, none of the participants reported that they were always confusing aspects to the course setup yet, $35 \%$ reported that they often face difficulties with the course setup. Finally, for the last item, if the students would like to take an online course in the future, $10 \%$ responded with always and $45 \%$ with often.

Analyzing the participants' responses, it is obvious that all courses were given online to the students; therefore, they feel overwhelmed with too much homework. Also, it can be seen that the participants strongly believe that the online learning community differs from a traditional setting and that the traditional classroom elements are lost in an online course. However, half of the participants stated that online teaching and learning is a good solution for the COVID19 pandemic, but the teachers should consider reducing the amount of homework given to the students because they felt that it was too much. It is very positive that the assessment and evaluation was being done fairly and objectively because assessment is a professional judgment about students work and progress in a course.

All in all, there are positive and negative sides of online teaching and learning and there are many areas of improvement

\section{INTERVIEW RESULTS}

In phase 2 of the research, there were 12 participants selected from the total sample of 65 students of both departments, English and German, to be interviewed. The interview questions 
were related to students' experiences with Google Classroom and Google Meet, online activities used by the teachers as well as the amount and the quality of the teaching materials posted by the teachers. The following are some excerpts taken from the interviews.

\section{Q1: Do you think that the Internet is playing a role in your study after the class? How or why not?}

P1: I think that the Internet is definitely playing a big role after classes. It helps me check the material, find good explanations of lectures, practice exercises, communicate with peers, etc.

P2: Internet is always a great way of self-study, which also helps in research and with other educational processes. Personally, whenever I have some doubts about a word or grammar, I tend to consult myself through the Internet, by using online dictionaries and books, and also because it is the fastest way.

P3: Yes, I think that it plays a huge role because it helps me to find additional materials, different quizzes to test my knowledge and also to find other materials except the ones that we use in classes, etc.

\section{Q2: Has the Internet helped you with your concerns about your study? How or why not?}

P3: Internet has helped me with my concerns several times. Whenever, I have questions or I need to find something related to the English language, I can freely get access to it.

P4: I can say sometimes it did, especially with German grammar, when I was stuck on a lecture that I couldn't understand and had no one around to help me, or when I didn't have my book with me while doing an exercise or an assignment.

P7: It definitely has assisted us, learning technology, classroom activities, also the internet is an endless library or encyclopedia, whether it's facts or fiction.

\section{Q3: What do you usually do with the Internet for English learning related purposes after class?}

P4: Mainly search the lectures, find good and simple explanations and definitions which we sometimes don't have in the book or are way too complex to understand from the first time reading them. I can say that in our town, outside university, there are no places where you can use or practice English (except private classes), so sometimes you really need the Internet to read or watch something in English. I also love to practice extra exercises just to be prepared and check my knowledge on the lessons. 
P6: The internet largely helps me conduct additional research in the English-related materials. It enables me to find extra materials regarding homework that are of huge importance for my performance in class.

P8: I tend to consult online dictionaries or get my research done with the help of the online references.

Q4: Do you have any exciting or depressing learning experiences with the online classes? If so, please be specific.

P10: My most exciting learning experience until this day would be building my vocabulary through watching YouTube videos, news and other diverse English contents posted for us, as well as reading PDF books. This is my own way of improving my English skills which is at the same time the most thrilling, as it is something I enjoy doing during my free time.

P11: Not really exciting, but I'm happy if I find a short video of the main topics presented to us by the teacher. I have always learnt with the Internet because it served as a study guide for me. No depressing experiences for now.

P2: Mostly, learning online throughout this time has been very exciting since we have to practice social distancing, we communicate with our colleagues and professors, which can be interesting during this time. This has not been so easy for us nor for the teachers.

\section{Q5: Why are you using the Internet most of the time?}

P9: I use Internet for three simple reasons: it is accessible, fast and reliable. Because of these characteristics, I use a lot of online references, also the online portals have improved a lot over time, with more detailed information/ explanation on every possible topic.

P10: One of the main reasons is because it is easy to access when you have Internet at your home or on your phone, also you can get very useful presentations, articles and videos for free, you don't have to go to the university library (it's free but you need time and transport), copy shop or any bookshop to buy a book with what you need.

P11: Apart from research, I use the internet as a main tool for my occupation as I am an online English teacher.

\section{How often were you commenting, posting, and communicating with your teacher and peers using Google Classroom?}

P1: I had never used it before coming to SEEU, and since I started using it, mostly the communication was homework related, talking and discussing the assignment. I enjoy Google Classroom a lot, it is a lot easier and useful during university studies, and one of the greatest 
characteristics is that I am able to contact freely my teacher regarding any concerns at any time.

P2: As often as I needed to, when the teacher asks for each of us to comment I did, but if its optional or just an announcement I'm not the type of person who immediately goes to type thank you or whatever. If the teacher gives a private comment on my work or asks me something about my assignment of course I always answered. I don't communicate with my peers on GC, we use another app.

P3: Every time that I had difficulties or questions, I would use Google Classroom to ask the teacher about it. The teacher responded to me immediately.

P4: Very often, whenever it is necessary.

\section{Which activities have you done in Google Classroom?}

P3: Usually it is for sharing the materials from classes as well as handing in the assignments. We had questionnaires there as well.

P4: We have had online quizzes in German, handouts with exercises and additional readings. P6: Homework, quizzes, in-class activities, presentations, and online discussions.

P8: Honestly, we had many activities and tasks. I can say that it was more than in traditional classes, but it was executed well.

\section{8: Did the teachers give you regular feedback on the assignments? Are you satisfied with this?}

P5: Teachers always gave me feedback on my assignments, sometimes it was very detailed, sometimes vaguer, but it had always helped me evaluate myself and my work, which I am very grateful for, knowing how many students there are.

P7: Yes, they did but I wish they gave more detailed feedback.

P9: No, my teachers didn't give a regular feedback. Honestly, I wasn't satisfied with that, there were cases when we really needed some feedback at least one piece of feedback in the class so we could know if the assignments are well done or all of us missed the topic, but the teacher didn't give feedback. Overall, I'm thankful for the few teachers who really tried to regularly give everyone feedback on our assignments, it was such a relief, especially because this is our 
first year and we really needed some help trough the loads of homework and assignments online.

P10: I think more detailed feedback is necessary.

\section{Q9: Do you have any concerns about the usage of Google Classroom?}

P4: I don't, everything looks fine so far, it works great for me and hopefully it is the same for my colleagues.

P7: No, surprisingly GC turned out to be a very helpful tool where we have all our material and assignments, you can see what you have and haven't done and the due dates. No concerns at all.

P9: Personally, I do not have any concerns, the professors were very helpful, understandable and punctual, which also maybe goes for us students too.

P11: No concerns at all, it worked well.

\section{Q10: Do you have any concerns about using Google Meet?}

P6: Google Meet is again another great app that helps in holding the lecture in such difficult times, and it is a lot more useful than I thought. While using it, I had the opportunity to attend my lectures without problems from home as long as there is good Wi-Fi connection, which is another thing. Anyway, I am very pleased with this application and I hope this semester it will be as useful and on hand to our studies as the previous one.

P7: Sometimes yes, the sound system wasn't always good and there were a lot of students who often didn't have a good quality Internet connection, including me, which left us with hearing only parts of some lectures, but Google Classroom was there with the material, so it wasn't a big deal for me, it was just an annoying situation when you lose a part of the lecture.

P10: I do not, since we used to facetime with our family and closer friends, Google Meet was similar and the only difference was that this app was used for school.

P12: Maybe a short training at the begging would be helpful.

The interviews held with the respondents yield some very interesting data regarding the use of Google Meet and Google Classroom and students' experiences with them. It is obvious that students are satisfied with these tools except for some technical issues such as poor internet connection and bad sound. The most used activities were quizzes, in-class activities, 
presentations, online discussions and the only area of improvement remains teachers' feedback which the participants consider should be given regularly and should be more detailed.

\section{REFLECTION PAPER RESULTS}

The third instrument used for the purpose of this research was the students' reflections which were a class requirement. The students were asked to reflect on the benefits and challenges of online teaching. Some of the questions that served as a guide to write a reflection paper were:

1) Describe the experiences with online learning; 2) Reveal the benefits and difficulties that you are facing during online learning; 3 ) Reflect on how the online classes were organized. 


\section{The following are some excerpts taken from students' reflections:}

\section{Reflection 1:}

Firstly, schools implementing online learning would have numerous results, one of which is a lack of face to face communication and interaction between professors and students. As a result of lack of face to face communication, certain students are going to experience difficulties in learning. Online teaching can be adapted to certain subjects only so much; many of them are nearly impossible to efficiently adapt online, so many students are going to be forced to spend much more time going over the material and self-teaching than what would happen in teaching face to face. There are some positives to this, however. More students will have education opportunities because of education becoming more convenient. This is very true for students, particularly ones who might have to work or cannot afford certain expenses related to education (e.g. transportation issues). This will open more opportunities for students to pursue an education as a result of schools becoming more flexible and tuition prices and payment becoming more negotiable. Better teaching technologies are going to be created because of increased use of technology. As a result of this increased use, new advancements in the tech industry are going to happen.

\section{Reflection 2:}

The semester was challenging for us due to global pandemic and the online classes. The online teaching has its' pros and cons. When it comes to timing it helps us a lot because we can take online classes anywhere as long as we have internet and we can be doing two things at once. You can log on the moment you get your notifications which means you most likely will be on time as long as you have your device with you, and even if you miss something from the lecture you can always go back and check it later online in the links that the professor sends.

However, some of the most difficulties we had is that some professors refuse to take online classes and they just send the material for the students to learn it by themselves, they give too much homework that could have been done in the online classes, and if we add the professors who don't even hold online classes and every work is given to the students as a homework, most of the times it is very hard to accomplish all of them.

\section{Reflection 3:}

Foremost, online learning seems very recent to some of us, although it has been in operation previously to the pandemic that we are facing these days. It is a tool used for the ones who are 
not able to attend university, people who are physically incapable of attending places out of their home or risky to them, even people who are taking online classes, completing their studies on the internet, may be even the cause of living overseas and due to the different international preferred universities. A person can prefer a university from a long distance and still be able to receive a degree.

A disadvantage may be considered, the progress can be somewhat difficult, and the traditional way is preferred, although the online learning has shown results where the students move faster through the parts of the course where it feels convenient for them, also it gives them full and adequate management.

Students' reflections reveal some positive aspects and challenges that students face in online learning. among which, the lack of face to face communication where certain students have trouble learning and they must spend much more time going over the material and self-learning than what would happen in teaching face-to-face. Also, too much homework, which could have been done during online classes is given to the students, and in some occasions professors just post the materials and the students have to study without being provided with the input. It is also a belief that the progress can be somewhat difficult, and the traditional way is preferred. Despite these negative points, online learning is suitable for those students who have to work or cannot afford certain expenses related to education (e.g. transportation issues). Additionally, when it comes to timing, it helps students a lot because they can take online classes anywhere as long as we they have access to the internet and they can do two things at once. Finally, the online learning environment can reach even the most distant learners and teaching technologies are going to be created because of increased use of technology everywhere. 


\section{CONCLUSION}

The results of the study reveal that most of the participants have a positive attitude towards the use of Google Classroom and Google Meet as online learning platforms during the COVID-19 pandemic at SEEU. Generally, the benefits of online teaching/learning outweigh the challenges and the teachers should work towards eliminating any difficulties students might have in order to achieve the learning goals.

Regarding the first research question: “What are the students' perceptions of online teaching at SEEU during the COVID 19-pandemic?", based on the questionnaire results, it could be observed that, all students $(100 \%)$ were taking online classes in all subjects of their study as this was a university decision and solution during crisis. Related to this, half of the participants find online teaching a good solution for the COVID-19 pandemic era and more than a half of them think that traditional teaching elements are lost in an online setting. They also expressed the concern with some confusing aspects to the setup of the course. Moreover, around half of them think that teachers have well managed the courses and the assessment and evaluation was done fairly by the professors.

Regarding the second research question: "What are the main challenges that the students faced during their online classes?", students' interviews revealed interesting results and the participants expressed that they use internet for different purposes such as: to do research, watch YouTube videos, download materials after the classes, etc. However, there are several challenges that they faced and the most mentioned ones were that the teachers did not give regular and detailed feedback to the assignments submitted on Google Classroom. One interviewee also mentioned that the amount of the materials posted was higher than in regular classes, and there were too many homework assignments given to them (student reflections and questionnaire results). Other than this, the participants find Google Classroom and Google Meet useful tools except for some minor technical difficulties like the quality of sound or internet connection. Regarding the teachers, they were very helpful, understandable and punctual, which may also be true for the students as well, but the students might experience difficulties because there is a lack of face-to-face communication (student reflections).

\section{Regarding the third research question: Which were the most posted online activities by the} teachers, the interview responses revealed that the teachers use different online activities. Google Classroom is used for sharing the materials from classes, posting assignments, online 
quizzes, handouts, additional readings, online discussions and power point presentations. One interviewee responded that they had questionnaires there as well.

Based on the overall findings, three important implications for teachers are proposed:

- Since the students' attitudes towards online teaching were generally positive, this helps with the implementation of online teaching and learning more successfully. This was also shown when the participants, more than half of them, reported that they would take an online course in the future because they are very satisfied with Google Classroom and its features.

- Given the research finding that most of the interviewed participants reported that the teachers did not give regular nor detailed feedback to their assignments, teachers should be encouraged to do so in the future. Receiving regular written feedback helps students to improve writing quality and skills, encourages critical reasoning, and promotes learners' autonomy.

- Finally, when planning the online classes, teachers should be very careful which content and amount of homework they give to the students. Technological availability nowadays helps teachers to assign and assess all homework online, but this should not exceed students' limits because too much homework makes their learning difficult. Within the grading tool of Google Classroom, teachers can send feedback to each student on assignments instantly. In order to have better results in doing homework, it is important to assign work that students can do and in small units which can help students understand the material covered in the online class.

- In conclusion, successful teaching whether it is online or onsite, needs to include discussion, cooperation and motivation. Both groups involved in the learning/teaching process, teachers and students, are more engaged in learning when they are motivated. Therefore, it is our responsibility as teachers to change and create opportunities for students to learn in any learning environment and real-life situation. Reflecting and improving our teaching practices can help us succeed and achieve our learning objectives even at the worst times such as the era of the COVID-19 pandemic. 


\section{REFERENCES}

- Cahoon, (1998). Teaching and learning internet skills. In B. Cahoon (ed.) Adult learning and the Internet (New directions for adult and continuing education), 78(2), 5-13.

- Executive summary posted by the United Nations (2020).Education during COVID -19 and beyond. Retrieved on September 7, 2020 from the web: https://www.un.org/ development/desa/dspd/wp-content/uploads/sites/22/2020/08/sg_policy_brief_covid19_and_education_august_2020.pdf

- Gilbert, B. (2015). Online Learning Revealing the Benefits and Challenges. Education Masters. Retrieved on August 25, 2020 from the web: https://fisherpub.sjfc.edu/education_ETD_masters/303

- Lee, C.and Lalani, F.(2020). The COVID-19 pandemic has changed education forever. This is how. World Economic Forum. Retrieved on September, 2020 from the web:https://www.weforum.org/agenda/2020/04/coronavirus-education-global-covid19online-digital-learning

- O'Donoghue, Singh, G. and Green, Ch.(2004). A comparison of the advantages and disadvantages of IT based education and the implications upon students. In: Interactive Educational Multimedia, Nr.9. pp. 63-76.

- Sloboda, B. (2005). Improving the teaching of statistics online: A multifaceted approach. In: Journal of Educators Online, 2(1), pp.1-13

- Stone, T.M and Perumean-Chaney, S. (2005).The Benefits of Online Teaching for Traditional Classroom Pedagogy: A Case Study for Improving Face-to-Face Instruction. In:MERLOT Journal of Online Learning and Teaching. Vol. 7, No. 3, pp.393-400 


\section{APPENDIX 1}

Dear student, please take some time and complete this questionnaire as a part of the research carried out at SEEU. Please, click the answer which applies to you.

Thank you for your time.

\begin{tabular}{|c|c|c|c|c|c|}
\hline \multirow{2}{*}{$\begin{array}{l}\text { Questions } \\
\text { 1. How often did you enroll for online classes last } \\
\text { semester? }\end{array}$} & Never & Rarely & Often & Sometimes & Always \\
\hline & & & & & \\
\hline $\begin{array}{l}\text { 2. Do you think that the online teaching/learning is } \\
\text { good solution for a pandemic period? }\end{array}$ & & & & & \\
\hline $\begin{array}{l}\text { 3. Have you faced any difficulties during this onlin } \\
\text { course? }\end{array}$ & & & & & \\
\hline $\begin{array}{l}\text { 4.Do you think that you have been a successful onl } \\
\text { learner? }\end{array}$ & & & & & \\
\hline $\begin{array}{l}\text { 5.Do you think that teachers were good in online } \\
\text { teaching? }\end{array}$ & & & & & \\
\hline $\begin{array}{l}\text { 6.Were you given too much homework during the } \\
\text { online classes? }\end{array}$ & & & & & \\
\hline $\begin{array}{l}\text { 7.Were there confusing aspects to the setup of the } \\
\text { course? }\end{array}$ & & & & & \\
\hline $\begin{array}{l}\text { 8. Do you believe that whiteboard is a useful tool } \mathrm{f} \\
\text { teaching/learning? }\end{array}$ & & & & & \\
\hline $\begin{array}{l}\text { 9. Do you think that the online learning community } \\
\text { differs from a traditional setting? }\end{array}$ & & & & & \\
\hline $\begin{array}{l}\text { 10. Did the online setting affect the discussion } \\
\text { between you and your peers? }\end{array}$ & & & & & \\
\hline $\begin{array}{l}\text { 11. Did the online setting affect the discussion } \\
\text { between you and your teacher? }\end{array}$ & & & & & \\
\hline $\begin{array}{l}\text { 12. Are there pieces of the traditional classroom } \\
\text { setting that are lost in an online course? }\end{array}$ & & & & & \\
\hline $\begin{array}{l}\text { 13. Do you need face-to-face interaction with your } \\
\text { peers and instructors to succeed? }\end{array}$ & & & & & \\
\hline $\begin{array}{l}\text { 14.Were the assessment and evaluation fair and } \\
\text { objective? }\end{array}$ & & & & & \\
\hline 15.Would you take an online course in the future? & & & & & \\
\hline
\end{tabular}




\section{APPENDIX 2}

\section{Interview questions}

1. Do you think that the Internet is playing a role in your English study after the class? How or why not?

2. Has the Internet helped you with your concerns about English study? How or why not?

3. What do you usually do with the Internet for English learning related purposes after class?

4. Do you have any exciting or depressing learning experiences with the Internet? If so, please tell me why it is exciting or depressing.

5. Why are you using the Internet, not other tools for the activities you mentioned?

6. Where necessary, how often were you commenting, posting, and communicating with your teacher and peers using Google Classroom?

7. Which activities have you done in Google Classroom?

8. Did the teachers give you regular feedback on the assignments? Are you satisfied with this?

9. Do you have any concern about the usage of Google Classroom?

10. Do you have any concerns about using the Google Meet? 